Journal of Scientific Perspectives

Volume 3, Issue 1, Year 2019, pp. 11-20

E - ISSN: 2587-3008

URL: http://ratingacademy.com.tr/ojs/index.php/jsp

DOI: $10.26900 /$ jsp.3.002

Research Article

\title{
BORON COMPOUNDS WITH MAGNETIC PROPERTIES AND THEIR APPLICATION AREAS IN INDUSTRY
}

\author{
Engin MEYDAN* \\ * Canakkale Onsekiz Mart University, Ezine Vocational School, Department of Food Processing, \\ TURKEY, E-mail: enginmeydan@comu.edu.tr \\ ORCID ID: https://orcid.org/0000-0002-1860-1715
}

Received: 2 January 2019; Accepted: 25 January 2019

\begin{abstract}
The importance of boron compounds with magnetic properties provide great convenience increasing day by day. In this study, boron compounds with magnetic properties and their application areas were investigated. In the study, firstly the boron element is given, then the usage of boron elements, the importance of boron compounds with magnetic properties and the methods of obtaining boron compounds with magnetic properties are mentioned. Finally, it was given information about catalytic applications of boron compounds and the study was completed by mentioning the contributions from agriculture to industry, medicine and food. In this study, document analysis method and content analysis were used.
\end{abstract}

Keywords: Boron, magnetism, nanoparticle, catalytic activity

\section{INTRODUCTION}

In this study, the structure, physical and chemical properties of boron elements, various boron minerals, the places where these minerals are located in nature and which sectors are used will be given. In the following stages, boron doped nanostructures will be explained and the studies about boron doped magnetic nanoparticles will be examined. When the literature is examined, there are many studies and compilation of boron atoms. However, the contribution of boron minerals has not been observed in recent technological developments. With this study, information is given about the purpose and how to use boron compounds in new generation technologies.

\subsection{Boron}

Boron; from glass industry to ceramics industry, from cleaning products to late burning agents, from agriculture to metallurgy, nuclear applications, where it is used is an important element and it's using increases everyday. In the known elements, the boron, which is considered to be the hardest element after diamond, has several amorphous and six polymorphic 
allotropes (Werheit et al., 2010). The structural and chemical proporties of boron (Tombal et al., 2016) and physical proporties (Bilgiç and Günık, 2013) are examined in the below tables.

Table 1.1. Boron atom structure

\begin{tabular}{|l|l|}
\hline Atomic diameter & $1.17 \AA$ \\
\hline Atomic volume & $4.63 \mathrm{~cm}^{3} / \mathrm{mol}$ \\
\hline Electron array & $1 \mathrm{~s}^{2} 2 \mathrm{~s}^{2} 2 \mathrm{p}^{1}$ \\
\hline Valence electrons & $2 \mathrm{~s}^{2} \mathrm{p}^{1}$ \\
\hline Electron number (no load) & 5 \\
\hline Ion diameter & $0,23 \AA$ \\
\hline Proton units & 5 \\
\hline Number of neutrons & 6 \\
\hline Crystalline & Rhombohedral \\
\hline
\end{tabular}

Table 1.2. Boron chemical proporties

\begin{tabular}{|l|c|c|c|}
\hline Electronegativity (Pauling) & \multicolumn{3}{|c|}{2,04} \\
\hline Electrochemical equation & \multicolumn{3}{|c|}{$0,1344 \mathrm{~g} / \mathrm{amp}$-sa } \\
\hline Potential energy of valence electrons (-eV) & \multicolumn{3}{|c|}{190} \\
\hline & $\begin{array}{c}1 . \\
\text { İonization } \\
\text { value } \\
\text { Ionization potential (eV) }\end{array}$ & $\begin{array}{c}2 . \text { ionization } \\
\text { value } 25,154\end{array}$ & $\begin{array}{c}\text { 3. ionization } \\
\text { value } \\
37,93\end{array}$ \\
\hline Fusion heat value & \multicolumn{3}{|c|}{$50,02 \mathrm{kj} / \mathrm{mol}$} \\
\hline
\end{tabular}

Table 1. 3. Boron physical proporties

\begin{tabular}{|l|c|}
\hline Atomic Mass & 10,811 \\
\hline Appearance & Yellow-brown ametalic and crystal \\
\hline Conductivity & Electrical: $1.0 \mathrm{E}-12106 / \mathrm{cm}$ \\
\hline Thermal Expansion coefficient & $0.0000083 \mathrm{~cm} /{ }^{\circ} \mathrm{C}\left(0^{\circ} \mathrm{C}\right)$ \\
\hline Density & $2,34 \mathrm{~g} / \mathrm{cc}-300 \mathrm{~K}$ \\
\hline Hardness & Mohs: 9,3 (Vickers: $\left.49000 \mathrm{M} \cdot \mathrm{N} . \mathrm{m}^{-2}\right)$ \\
\hline Flexibility status & Bulk: $320 / \mathrm{GPa}$ \\
\hline Enthalpy & $22,13 \mathrm{kj} / \mathrm{mol}\left(25^{\circ} \mathrm{C}\right)$ \\
\hline Enthalpy (Fusion) & $480 \mathrm{kj} / \mathrm{mol}$ \\
\hline Enthalpy (Evaporation) & $489,7 \mathrm{kj} / \mathrm{mol}$ \\
\hline Heat (Evaporation) & $0,348 \mathrm{~Pa}-2300{ }^{\circ} \mathrm{C}$ \\
\hline Pressure value (Steam) & $2573 \mathrm{~K}-2300^{\circ} \mathrm{C}-4172{ }^{\circ} \mathrm{F}$ \\
\hline Melting point & $1,02 \mathrm{~J} / \mathrm{g} . \mathrm{K}$ \\
\hline Specific heat value & $4275 \mathrm{~K}-4002^{\circ} \mathrm{C}-7236^{\circ} \mathrm{F}$ \\
\hline Boiling point & $4,68 \mathrm{~cm} 3 / \mathrm{mol}$ \\
\hline Molar volume & $20^{\circ} \mathrm{C} \mathrm{ve} 1 \mathrm{~atm}:$ Solid state \\
\hline Physical form & \\
\hline
\end{tabular}


Compared to other elements in nature, boron is the 51st element in the world. There are about 230 minerals in the boron, and can not be found in the free state on the earth. Turkey and the United States are removed most reserves of mineral resources, but the world is limited. While the amorphous boron can react immediately with any substance, its tendency to react decreases as its crystallinity increases, and completely crystalline boron does not react with anything. It reacts with water at high temperatures and forms boric acid (Demir, 2006).

\subsection{Usage Areas of Boron Element}

Boron element used in many areas of industry; insulation, ceramics and their derivatives, cleaning materials, fire extinguishers, agricultural areas, material engineering technologies, health, detergent, cosmetics, construction sector, especially in the construction of many sectors such as cement. It is used in many industrial sectors to get more energy and efficiency. It is thought to bring many innovations from the technological point of view (Garrett, 1998).

For example, boron element is used to increase the hardness and durability of the steel. Up to $50 \mathrm{ppm}$ of boron can be added to the structure of steel. This process is called boronizing. The surfaces of the steels produced by boronizing to convert steel more harder. In this way, some steel types used in heavy industries (such as large drills, hydraulic machines of construction machinery) become more durable (Şengönül et al., 2016).

Boron minerals are frequently used in the production of glass and its derivatives. The boron minerals are added to the prepared molten glass intermediate to increase the flowability of the material obtained and at the same time increase the surface resistance of the final product. Boron and its derivatives in glass industry are commonly used in glass fibers which are used as insulation intermediates. However, it is also used in sports equipments. In recent years, it has started to be used in aerodynamic industries such as planes, space ships, and all air platforms which based on aerodynamic properties (Yiğitbaşıŏglu, 2004).

Boron compounds can be used in aircraft as part of the fuel. The high flammability, though flammable, shows that it is advantageous for use in the transportation sector. Boron compounds can be also used in missile (rockets.. etc.) fuels because boron compounds give high performance to them (Çetin et al., 2003).

In nuclear reactors, many compounds are used such as boron carbide, boron-containing steels and titanium-boron alloys because of the neutron retention feature in the storage of waste (Karaçay et al., 2012).

Boron, which helps the balance of calcium, magnesium and phosphorus in metabolism, also increases the development and resistance of bones, muscles, allergic symptom treatments, psychiatric disorders. Boron compounds is used in the destruction of cancer cells and it is widely used in medicine (Proximity and Root, 2016).

Boron derivatives such as sodium perborate are widely used in the cleaning and hygiene industry. Boron and its derivatives which have many effects such as bleach, bactericidal and whitening, give effective results in cleaning stages thanks to the active oxygen which is found abundant in content. It also performs many processes such as softening, strengthening and extensively in cosmetic areas (Yenmez, 2009).

Boron derivatives such as colemanite, which are used in the development of the cement sector, provide many properties to cement structure such as water and gas permeability, durability. In addition, these compounds reduce by $\% 25-30$ the amount of $\mathrm{CO}_{2}$ released into nature (Yenialaca, 2009). 
In the glaze formation and generally in the ceramics industry, boron compounds are used between \% 8-24 in proportion to their weight. In this way, the mechanical resistance of the ceramics and also their thermal expansion increases. At the same time, infrastructure is formed in various coloring processes (Benedict, 1994).

Boron element, which has many effects on plant cell functions, undertakes various tasks in primarily cell division and photosynthesis processes. Because of the effects on sugar metabolism, it was determined that plants can not produce enough fruit or seed without boron. In many structures such as roots, flowers and buds, boron element is shown as one of the main production sources of plants (Ediz and Özdăg, 2001).

Boron compounds are used such as fire extinguishers or decelerators. In various polymers such as PVC, which we use in our daily lives, addition of boron compounds such as zinc borate to the structure as a additives, combustion retardant polymers are obtained. At the same time, the release of toxic gases to the nature can be prevented in the case of combustion (Aydin et al., 2016).

\subsection{Importance of Boron Compounds with Magnetic Properties}

In virtue of the boron and densely metal atoms in the transition metal borates, it is found suitable for use in new generation technologies and the studies are continuing in various fields. Through formed by using metal atoms in the magnetic field, the materials obtained can be collected or removed from the medium. Transition metal borates using in magnetic fields can be used in various reactions (Kronmüller, 2007).

When the transition metal borates are examined, the elements with the highest magnetic effect in the metals which are found as pure in nature are $\mathrm{Fe}, \mathrm{Co}$, Ni elements which are below the Curie temperature. These elements exhibit ferromagnetic properties, that is, they can have 1000 times more magnetic effects than a normal paramagnetic material. It has also been found that these compounds have these ferromagnetic properties in their compounds (Berg et al., 2001).

Boron containing compounds are used to direct magnetic interactions between the exchange mechanism and all metal ions. Therefore, magnetism has been used for a long time in various materials with boron content and metal added and it is aimed to produce promising technologies for the future (Spaldin, 2006).

Boron hydrides are substances which can be used as a very good hydrogen carrier and storage. Among the boron hydrides, sodium boron hydride compound is the most widely used industrial field. This compound is used in various sectors such as textile, paint, paper and agriculture for various purposes. The fact that the amount of hydrogen stored by boron derivatives is quite good, because it is compatible with nature shows the potential to be used as fuel in the future. Furthermore, there are many studies related to boron hydrides used in particularly the reduction of toxic waste and in the synthesis of magnetic metal nanoparticles. (Y1lmaz and Şefik, 2017).

\section{MATERİAL AND METHODS}

Before this study, the use of boron, its derivatives, their effects in industrial areas, and the latest technological developments about using boron have been examined. As a result of the investigations, studies that are different from each other and open to innovation are examined and processed in this article. Boron and its derivatives, which have a very important place among the promising technologies, have been determined as a result of the studies. In this study, document analysis was carried out on qualitative research methods. "Document review, the investigation includes examination of written materials containing information about the 
targeted case or cases" (Yıldırım and Şimşek, 2006). Although this approach is generally used in the field of social sciences, it is possible to use it in the state tray in the field of quantitative sciences in relation to the works to be carried out.

\section{RESULTS}

\subsection{Usage of Boron-containing Magnetic Metal Nanoparticles}

As industrialization increases and industrialization is carried out almost everywhere in every passing day, the chemicals that are mixed as waste into nature give great damages to the earth. Many natural catastrophes are realized due to the inability of inadequatly audits, the lack of adequate filtering, low recycling of industrial enterprises and the increasingly desensitization of societies. Due to the boron doped metal nanoparticles, some of these harmful compounds can be removed from the nature. In recent years, the catalytic effects of magnetic nanoparticles have been investigated by transformations in various organic compounds. Due to its stable and high surface area, it has taken its place in the scientific world as heterogeneous catalysts. Therefore, it has been determined that it has many advantages such as being cheap and having high surface area and also having the advantage of being more and more effective catalyzable and being recyclable by using magnetic effect. Studies have shown hopeful results (Ekomasov et al., 2015).

For example, gold, under normal conditions do not tend to react, but gold nanoparticles which are nanometric dimension showed various catalytic activities. They also exhibit various functional properties along with nanoparticle formation in other metals which are inert under normal conditions. The desired catalytic yield can also be increased by the materials used for the formation of nanoparticles. Highly effective nanocatalysts can also be synthesized by incorporation of compounds such as boron-containing sodium borohydride into the formation of nanoparticles (Buil et al., 2010).

Nanocatalysts are heterogeneous catalysts prepared as metal nanoparticles to accelerate catalytic processes. Boron and derivatives such as sodium boron hydride can be used in the synthesis. As they have high surface areas, they form more activated complex and their catalytic activity is higher than their equivalent catalysts. Metals can be recovered by various properties such as magnetic effect (Fukui et al., 2004).

The modified metal nanoparticles are more stable in the environment when compared to metal nanoparticles that do not contain any function. In nanoparticle synthesis, micelles can be formed using surface activating agents and nanoparticles can be synthesized. It is seen as a disadvantage that they are too close to be affected by van der Waals force. Because the active surface area is reduced as they are collected (Roucoux et al., 2002).al., 2002).

Methylen blue is used as a colorant in tissue analysis, in the leather industry, in the photocopy industry, in the photographic industry, in semiconductors, in the fluorescent light. Although there are many advantages, methylene blue has a high percentage of poison content. This compound contaminates the soil and water as a waste. At the same time, it is damaged in living creatures. It is possible to disintegrate and become harmless via boron compounds (Xia et al., 2011).

The nitro compounds, which are widely used in the industry, are polluted soil and water by factory wastes. No matter how little the content of nitro-based compounds are inhaled or in contact with the body, it may cause poisoning and death by affecting the components in the structure of the blood. For this reason, it is possible to remove these compounds polluting the nature or, if possible, to be reduced to the recyclable amine compounds which can be reused in the industry using a variety of catalysts. Many operations are carried out to remove this factory waste. There are many methods such as photocatalytic decay, ectrokoagulation, microwave 
assisted catalytic oxidation, adsorption, electro-fenton method, elelectrochemical processes (Chuang and Chen, 2009).

Aromatic nitro compounds which damage the nature can be reduced to aromatic amine groups which can be used as intermediate raw materials in various industrial areas such as pharmaceuticals, cosmetics, drugs by reduction-oxidation method. At the same time, methylene blue can be disintegrated from the nature by this method. In this study, the removal of the substances which damage the nature by using the reduction-oxidation method of boroncontaining metal nanoparticles were investigated. Microemulsion technique was used to obtain boron compounds with magnetic properties. The boron-containing magnetic metal nanoparticles synthesized by this technique and it have been used in the reduction of nitro compounds to amine compounds (Chuang and Chen, 2009).

\subsection{Catalytic Studies of Boron-containing Magnetic Metal Nanoparticles}

If Chuang and Chen's study is examined, chitosan is preferred to obtain nanoparticle because of its active surface area and most importantly it is one of the polymer derivatives in nature. The surface of chitosan, a natural polymer, was coated with oxidized compounds of iron, a magnetic element, to give magnetic properties to chitosan. Then it was modified by adsorption to this structure synthesized using Au nanoparticles. These prepared Au-based magnetic nanoparticles were studied as catalysts in catalytic experiments. The catalytic performance of the nitro compounds in the reduction reaction to the amine compounds was analyzed in the presence of $\mathrm{NaBH}_{4}$. The reduction reaction was determined by using UV-Vis spectroscopy. When the obtained data were analyzed, it was determined that the reduction reaction took place in a shorter period compared to the equivalents in the literature (Chuang and Chen, 2009).

Boron doped nanoparticles formed with metal ions having different oxidation steps such as $\mathrm{Co}, \mathrm{Fe}, \mathrm{Ni}, \mathrm{Ru}, \mathrm{Cu}, \mathrm{Au}$, which are placed in the hydrogel can give a reduction reaction in the hydrogel. These hydrogel-supported metal nanoparticles can be effectively used for the reduction of toxic substances such as nitro compounds, dye-added compounds, chlorohydro carbons, pesticides. In this study, preparation of structures, their catalytic effects and the frequency of change in the amount of toxic substances were analyzed (Sahiner, 2013).

The hydrolysis of $\mathrm{NaBH}_{4}$ using $\mathrm{Co}$ and $\mathrm{Ni}$ metal nanoparticles based on micro gels was investigated. As a result of the studies, boron-containing Co nanoparticles have been found to have an effective catalytic performance (Sahiner and Sağbaş, 2013).

It has been found that metal nanoparticles containing hydrogel-supported sodium boron hydride with magnetic properties can be used to remove pollutants and toxic metal ions. The studies carried out by Uv-Vis. device repetitively. Removed metal ratios were also calculated (Sahiner et al., 2009).

The catalytic effect of the nanoparticles synthesized using silver metal and boroncontaining substances together with the $\mathrm{NaBH}_{4}$ reductant was investigated. It is aimed to obtain the amine compounds which are used in the pharmaceutical and agricultural industries by reducing the nitrogenous substances which are thrown into the nature and toxic compounds. For this purpose, the reduction reactions of 4-Nitrophenol, 4-Nitroaniline and 2-Nitrophenol were analyzed. The catalytic effects in all reactions were determined under UVVis.spectroscopy. It has been found when $\mathrm{Ag}$ metal nanoparticles used as catalysts in the presence of $\mathrm{NaBH}_{4}$, started the reduction of aromatic nitro compounds and converted nitro groups to amine groups (Pradhan et al., 2002).

$\mathrm{Si} / \mathrm{Pd}$ nanoparticles were synthesized to used for methylene blue degradation reaction and silver nitrate solutions were used as support. This nanocatalyst, which is very fast and has 
high catalytic activity, is disadvantageous due to the use of expensive metals. In this study, copper microspheres was used as a catalyst to decompose dyes such as synthesized, eozin y (EY) and methylene blue (MB). These micro-scale and metal-based substances give effective catalytic activity results in the degradation reactions of dyes. It has been determined that the catalytic activities of the same microspheres have continued as a result of repetitvely well. Since the $\mathrm{Cu}$ element is cheap and can be found abundantly and also has a high surface area, it is considered advantageous to use it as a catalyst (Xia et al.).

Metal-containing chronographs were synthesized. Catalytic effects of methylene blue degradation and reduction of nitro compounds were investigated. In this study, metal nanoparticles were synthesized with using $\mathrm{NaBH}_{4}$ and $\mathrm{Co}, \mathrm{Fe}, \mathrm{Ni}, \mathrm{Cu}$ metals. Then, methylene blue degradation, reduction of 4-Nitrophenol to 4-Aminophenol were investigated the presence of Uv-Vis. spectrophotometry. Compared to the literature is quite good activation energy, enthalpy and entropy values were determined (Sahiner et al., 2015).

In the doctoral thesis of Meydan (2018), Co nanoparticles which have many advantages such as high surface area, cheap metal preparation and magnetic properties were synthesized. Because of the factory wastes and agriculturel wastes, nitro compounds come to exist and pollute all the enviroment. It is necessary to destroy these nitro compounds which are very harmful before damaging the nature. These nanoparticles are intended to be used as catalysts in order to convert harmful nitro compounds to amine groups that can be used as raw materials in the pharmaceutical industry. In addition to the conversion of aromatic nitro compounds to aromatic amine groups, the activation energy values required for the actual transformation are also important parameters. The studies have been compared with the reduction reactions of the nitrophenol compound by using different nanoparticles with different contents of different scientists. The table which is formed by finding the activation energies of the nanoparticles that other scientists have synthesized for the reduction reaction of nitro compounds is given below. As a result of the comparisons, it was determined that the activation energy value of Co nanoparticles obtained was lower than the activation energies obtained in other studies. The activation energy value found at $32.1 \mathrm{kj} / \mathrm{mol}$ was found to be quite low from the values in all other studies. Therefore, in order to realize a chemical reaction, the particles with the lowest energy value to be exceeded were determined as a result of the data compared to the studies examined with Co nanoparticles (Meydan, 2018).

Table 3.1. Comparison of activation parameters

\begin{tabular}{|c|c|c|c|c|}
\hline Catalysts & $\begin{array}{c}\mathrm{Ea} \\
\left(\mathrm{kJmol}^{-1}\right)\end{array}$ & $\begin{array}{c}\Delta \mathrm{H} \\
\left(\mathrm{kJmol}^{-1}\right)\end{array}$ & $\begin{array}{c}\Delta S \\
\left(\mathrm{~J} \mathrm{~mol}^{-1} \mathrm{~K}^{-1}\right)\end{array}$ & References \\
\hline $\mathrm{G} 4-\left(\mathrm{Cu}_{16}\right)$ & 65,5 & - & - & Nemanashi and et al. 2013 \\
\hline $\begin{array}{l}\text { PS-PEGMA-Ag } \\
\text { system }\end{array}$ & 62,0 & - & - & Lu and et al. 2006 \\
\hline Au nanocatalyst & 51,2 & - & - & Chuang and Chen 2009 \\
\hline Co-Ni-rGo composite & 49,94 & - & - & Prasad and et al. 2016 \\
\hline $\begin{array}{l}\mathrm{p}(\mathrm{APTMACl})-\mathrm{Cu} \\
\text { composite microgels }\end{array}$ & 47,90 & - & - & Rehman and et al. 2015 \\
\hline Co Nanoparticles & 32,1 & - & - & Meydan 2018 \\
\hline
\end{tabular}


It is known that the nanoparticle with the lowest activation energy has the fastest catalytic effect. As a result of the investigations, it was found that the nanoparticle having the lowest activation energy was the metal nanoparticles synthesized by Meydan and the reduction of nitrophenol to the aminophenole was faster than the other nanoparticles.

\section{DISCUSSION}

In this study, boron and its derivatives, their industrial applications, boron compounds with magnetic properties are given. It has been seen that boron compounds which have magnetic properties through previous research have an important place in many industrial fields from agriculture to construction, from medicine to food. Thanks to its useful properties, it has been found that boron compounds which have magnetic properties provide advantages in many sectors within the usage areas and they are important for the future.

It has been determined that boron-containing nanoparticles with magnetic properties can destroy many nature-threatening compounds such as plants and agricultural wastes or convert them into other substances that can be used as intermediates. Promising results were found for the future. For this reason, studies on boron compounds with magnetic properties can be developed and also economic, healthly, environmentally, human life-facilitating products can be worked on and various projects can be designed to prevent the pollution of nature.

\section{RECCOMMENDATION}

In our country, the use of boron element, which is abundant as a raw material mine compared to other countries in the world, can not be processed enough. And it is also very important in terms of strategic aspect. For this reason, new technologies should be brought to our country for the use of boron. Activities, seminars and conferences related to boron and its derivatives should be increased. In our country, all our mines, such as boron found in abundance, should be explained to the generations to start with primary school. The main point is to process new technologies rather than using them as raw materials. The use of this precious mine is very important for the advancement of new generation technologies in our country. It can also make a significant contribution to our country's economy.

Recycling systems can be increased by using new generation catalytic systems and factory waste which is one of the biggest problems of today can be destroyed. Thanks to the new generation of catalytic systems and catalysts to be prepared through new generation technologies, harmful substances which poison nature and humanity can be transformed into useful products for humanity. Therefore, we need to know more about the importance of our values and work harder. In this way, a cleaner world can be left to future generations. 


\section{REFERENCES}

Aydın Y. D., Gürü M., Ayar B., Çakanyıldırım Ç., 2016. Bor bileşiklerinin alev geciktirici ve yüksek sıcaklığa dayanıklı pigment olarak uygulanabilirliği, Bor Dergisi,Cilt 1, 1,33-39.

Benedict, T. L. 1994. A New Twist to Glass Fiber. 47. Ceramic Ind., v. 143, pp. 60-61.

Berg K. C., Chapman K. J., 2001. Determination of the Magnetic Moments of Transition Metal Complexes Using Rare Earth Magnets, Journal Chemical Education, 78(5), 670.

Bilgiç M.,Dayık M., 2013. Borun Özellikleri ve Tekstil Endüstrisinde Kullanımıyla Sağladığı Avantajlar, Tekstil Teknolojileri Elektronik Dergisi Cilt: 7, No: 2, 27-37.

Buil M. L., Esteruelas M. A., Niembro S., Olivan M.,Orzechowski L., Pelayo C., Vallribera A., 2010. Dehalogenation and Hydrogenation of Aromatic Compounds Catalyzed by Nanoparticles Generated from Rhodium Bis (imino) pyridine Complexes, Organo metallics, 29 (19), 4375-4383.

Chuang Y. C., Chen D. H., 2009. Catalytic Reduction of 4-nitrophenol by Magnetically Recoverable Au Nanocatalyst, Journal of Hazardous Materials, 165, 1-3, 664-669.

Çetin İ., A., Ordu İ., Kolip A., 2003. Yakıt Hücresi Teknolojisinde Bor Uygulamaları, Sakarya University Journal of Science, Cilt 7, 2, 257 - 264.

Demir C., 2006. Bor Minerallerinin Enerji Kaynă̆ı Olarak Değerlendirilmesi, Selçuk Üniversitesi Kimya Mühendisliği Bölümü Yüksek Lisans Tezi, Konya, Türkiye.

Ediz N., Özdağ H., 2001. Bor Mineralleri ve Ekonomisi, Dumlupınar Üniversitesi Fen Bilimleri Enstitüsü Dergisi, 2, 133-151.

Ekomasov E. G., Murtazin R. R., Nazarov V. N., 2015. Excitation of magnetic in homogeneities in three-layer ferro magnetic structure with different parameters of the magnetican isotropy and exchange, Journal of Magnetism and Magnetic Materials, 385, 217-221.

Fukuia T., Murataa K., Oharab S., Abec H., Naitoc M., Nogic K., 2004. Morphology Control of Ni-YSZ cermetanode for lower temperature operation of SOFCs, Journal of Power Sources, 125, 17-21.

Garrett D., 1998. Borates: Handbook of Deposits, Processing, Properties and Use, San Diego, Academic Press, 11-14, USA.

Kronmüller H., Parkin S., 2007. vol. 5: Spintronics and Magnetoelectronics, John Wiley and Sons Ltd., USA.

Karaçay E., Alp E., Cabbar H. C., 2012. Sol-Jel Yöntemiyle Bor Karbür Üretimi ve Karakterizasyonu, Gazi Üniversitesi Mühendislik-Mimarlık Fakültesi Dergisi, Cilt 27, 2, 417-428.

Lu Y., Mei Y., Walker R., Ballauff M., Drechsler M., 2006. 'Nano-tree'typesphericalpolymerbrushparticles as templatesformetallicnanoparticles, Polymer, 47, 4985-4995.

Nemanashi M., Meijboom R., 2013. Synthesis and characterization of $\mathrm{Cu}, \mathrm{Ag}$ and Audendrimer-encapsulated nanoparticles and their application in ther eduction of 4nitrophenol to 4-aminophenol, Journal of Colloid and Interface Science, 389, 260-267

Meydan, E., 2018. Manyetik Özelliğe Sahip Bor Bileşikleri ve Bunların Katalitik Uygulamaları. Çanakkale Onsekiz Mart Üniversitesi Fen Bilimleri Enstitüsü Yayınlanmamış Doktora tezi, 90 s. Çanakkale.

Pradhan N., Pal A., Pal T., 2002. Silver nanoparticlecatalyzed reduction of aromatic nitro compounds, Colloidsand Surfaces A: Physicochemical and Engineering Aspects, 196, 2-3, 247-257. 
Prasad R., Lolakshi M.K., Bhat B. R., 2016. rGOsupported Co-Nibimetallic magnetically separable nanocatalysts for the reduction of 4-Nitrophenol, Synthetic Metals 219, 26-32.

Rehman S., Siddiq M., Al-Lohedan H., Sahiner N., 2015. Cationicmicrogelsembedding metal nanoparticles in thereduction of dyesandnitro-phenols, Chemical Engineering Journal, 265, 201-209.

Roucoux A.,Schulz J., Patin H., 2002. Reduced Transition Metal Colloids: A Novel Family of Reusable Catalysts?, Chemical Reviews, 102 (10), 3757-3778.

Sahiner N., 2013. Soft and flexible hydrogel templates of different sizes and various functionalities for metal nanoparticle preparation and their use in catalysis, Progress in Polymer Science, 38, 9, 1329-1356.

Sahiner N., Sagbas S., 2013. Tunablepoly (2-acrylamido-2-methyl-1-propan sulfonicacid) based microgels with beter catalytic performances for $\mathrm{Co}$ and $\mathrm{Ni}$ nanoparticle preparation and their use in hydrogen generation from $\mathrm{NaBH}_{4}$, International Journal of Hydrogen Energy, 37, 18944-18951.

Sahiner N.,Yildiz S., Al-Lohedan H., 2015. There source fulness of $\mathrm{p}(4-\mathrm{VP})$ cryogels as template for in situnanoparticle preparation of various metal sand their use in $\mathrm{H}_{2}$ production, nitrocompound reduction and dyedegradation, Applied Catalysis B: Environmental, 166-167, 145-154.

Spaldin, N. A., 2006. Magneticmaterials: Fundamentals and device applications (Repr. ed.). Cambridge: Cambridge Univ. Press, pp. 89-106.

Şengönül M., Durgun İ., Dökmetaş N., Kalkan H., Kaftanoğlu B., 2016. Bor Nitrür Kaplamanın, Kaynak Çapaklarının Metal Aparat Yüzeylerine Yapışma Davranışlarına Etkisi, Makine Tasarım ve Imalat Dergisi, Cilt 14, 1, 23-30.

Tombal D., T., Özkan G., Ş., Ünver İ., K., Osmanlığlu A., E., 2016. Bor bileşiklerinin özellikleri, üretimi, kullanımı ve nükleer reaktör teknolojisinde önemi, Bor Dergisi, 2, 85-96.

Werheit H., Filipov V., Kuhlmann U., Schwarz U., Armbrüster M., Leithe-Jasper A., Tanaka T., Higashi I., Lundström T., Gurin V.N., 2010. Raman effect in icosahedralboronrichsolids, Science and Technology of Advanced Materials, 11, 2, 1-27.

Xia L., Zhao H., Liu G., Hu X., Liu Y., Li J., Yang D., Wang X., 2011. Degradation of dyesusinghollow copper microspheres as catalyst, Colloids and Surfaces A: Physico chemical and Engineering Aspects, 384, 358- 362.

Yakıncı D. Z., Kök M., 2016. Borun Sağlık Alanında Kullanımı, İn̈̈ӥ̈ Üniversitesi Să̆lık Hizmetleri Meslek Yüksek Okulu Dergisi, Cilt 4, 1, 36-44.

Yenialaca Ç., 2009. Bor ve Kullanım Alanları, (Y. Lisans tezi) Gazi Üniversitesi, Gazi Eğitim Fakültesi, Fizik Eğitimi Bilim Dalı, Ankara.

Yenmez N., 2009. İstanbul Üniversitesi Edebiyat Fakültesi Coğrafya Bölümü Coğrafya Dergisi Stratejik Bor Maden Olarak Bor Minerallerin Türkiye İçin Önemi 19, 59-94.

Yıldırım, A., Şimşek, H. (2006). Sosyal Bilimlerde Nitel Araştırma Yöntemleri. Ankara: Seçkin Yayıncılık.

Yılmaz A., Şefik S., 2017. Sodyum Borhidrür $\left(\mathrm{NaBH}_{4}\right)$ Destekli Bir Hidrojen/Hava PEM Yakıt Hücresi İle Elektrik Üretiminin Deneysel Analizi, Batman Üniversitesi Yaşam Bilimleri Dergisi 7, 216-227.

Yiğitbaşığlu H., 2004. Türkiye İçin Önemli Bir Maden: Bor Ankara Üniversitesi, Coğrafi Bilimler Dergisi, Cilt 2, 2, 13-25. 